\title{
Marine geophysical investigations offshore East Greenland
}

\author{
H. C. Larsen and M. S. Andersen
}

During August and September 1981 a marine geophysical survey was conducted on the shelf of East Greenland. The survey consisted of two programmes, one being part of the ongoing regional project NAD (Andersen et al., 1981; Risum, 1980, and Larsen \& Thorning, 1980 ), and the other being a small programme in the Denmark Strait (fig. 26). In all 2388 $\mathrm{km}$ of 24-fold multi-channel seismic data and marine gravity and magnetic data were acquired.

The objective of the NAD programme is to acquire regional coverage of aeromagnetic, multi-channel seismic reflection, seismic refraction (sonobuoy), marine gravity and magnetic data of the East Greenland Shelf between latitudes $60^{\circ} \mathrm{N}$ and $78^{\circ} \mathrm{N}$. Aeromagnetic data comprising 63000 line kilometres were acquired in 1979 (Larsen \& Thorning, 1980) and $2610 \mathrm{~km}$ of marine geophysical data were acquired in 1980 (Andersen et al., 1981). It is anticipated that the NAD acquisition programme will be completed in 1982 after a further four weeks marine geophysical survey.

The objective of the Denmark Strait programme is to map the deeper structure and subsurface configuration of what is assumed to be the basaltic basement of this region (Larsen, 1980), and to obtain stratigraphic information of the overlying sedimentary succession with special emphasis on the evaluation of the subsidence history of the region.

\section{Survey vessel and instumentation}

Seismic Profilers, Oslo, were contracted for the 1981 survey. The 2400 ton seismic vessel R/V Nina Profiler equipped with a DFS V seismic recording system, a $2400 \mathrm{~m}$ teledyne transformerless streamer, and a 3640 cubic inch (2000PSI) airgun array was used for the survey operations. Coverage was 24 -fold (48 trace recording) with $50 \mathrm{~m}$ shot point intervals during the whole survey, allowing an average shooting speed of 6.8 knots. With the exception of $85 \mathrm{~km}$ of profile, the same energy source was used consisting of four, $20 \mathrm{~m}$ long sub-arrays, each with a total volume of 910 cubic inches ( 7 Bolt airguns); they were towed fairly close together. During the first $85 \mathrm{~km}$ of surveying, a $60 \mathrm{~m}$ wide airgun array with identical volume was applied, but it was found impracticable to operate in the pack ice.

Gravity and total field magnetic data were obtained using a LaCoste \& Romberg marine gravity meter and a Geometrics G803 marine magnetometer. The integrated use of Loran-C, NavSat and sonar-doppler provided the necessary positioning throughout the survey, although Loran-C was not very useful south of latitude $65^{\circ} \mathrm{N}$.

The Danish Hydraulic Institue (DHI) was contracted to provide real time information on the regional ice pattern. This was obtained from satellite images and special ice reconnaissance flights from Reykjavik during August and September. This information, together with ice data and special weather forecasts were transmitted to the survey vessel by facsimile from the Danish Meteorological Institute. A Hughes 500D helicopter was carried onboard to provide short range, detailed ice information. The helicopter was chartered from Bergquist Helikopterservice A/S, Ringsted, through Greenlandair Charter A/S. 


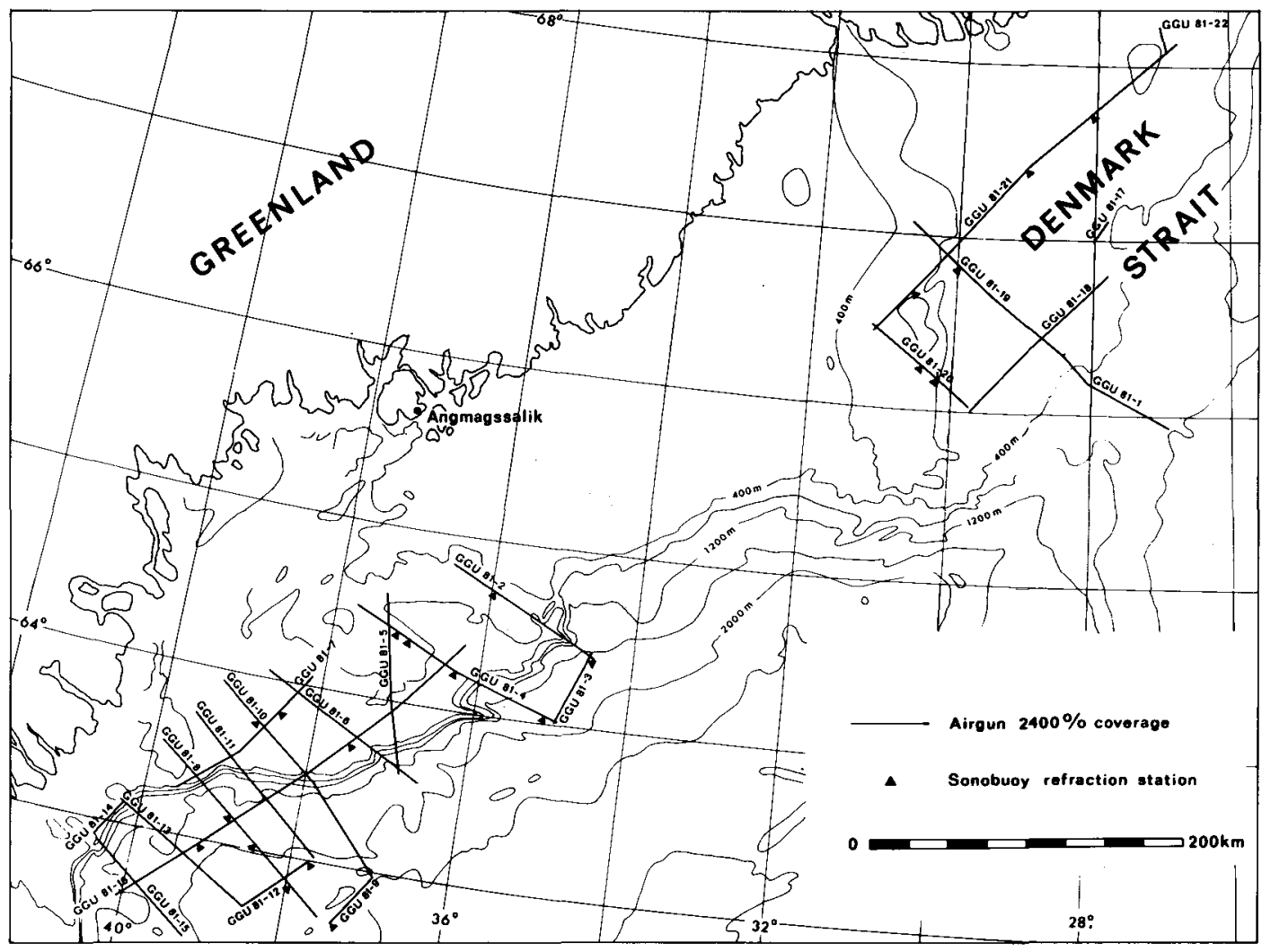

Fig. 26. Profiles acquired within the 1981 seismic survey with R/V Nina Profiler.

\section{The survey}

The survey vessel embarked from Reykjavik on August 10th and returned to Reykjavik after completion of the survey on September 28th. However, during the survey, unscheduled port calls were made to Reykjavik from August 17th to 21th and from 25th to 27th following problems with the ship's propeller pitch control and damage to airguns due to pack ice interference. A port call was made to Angmagssalik September 12th to 13th to collect spares and food. Finally the ship stayed in Isafjorður, north-western Iceland (see below) from September 26th to 27th. Accordingly, the main investigation took place between August 29th and September 25th.

The weather in general was the main hindrance to data collection. The mean wind force and sea state (Beaufort) was 4.7 and 3.6 respectively during the survey period (fig. 27). However, as a result of a high technical standard onboard, and a high shooting speed (6.8 knots on average) a remarkably high production rate was maintained within the limited periods of good weather. Also, owing to the stability of the ship, work was maintained during periods of marginal weather. 


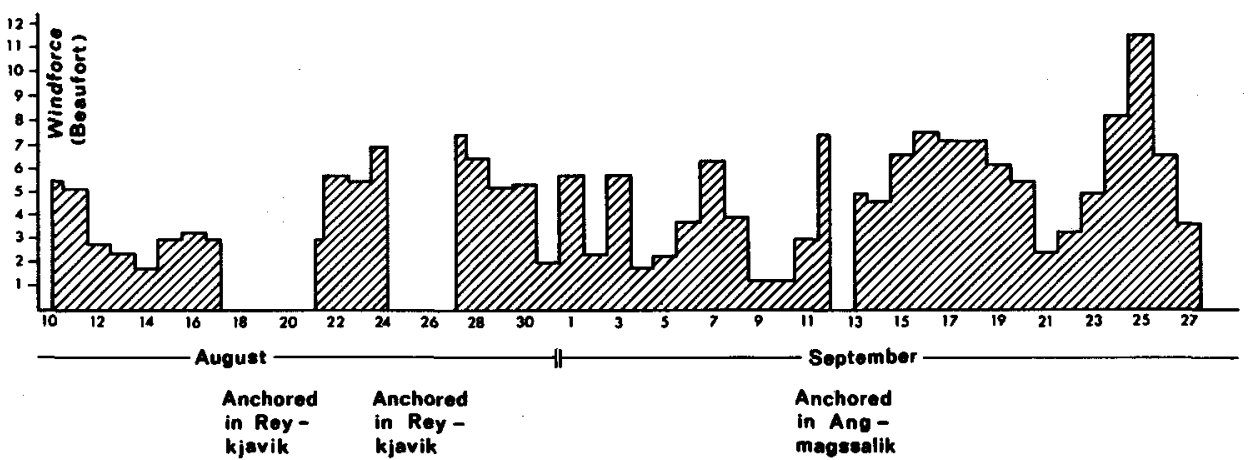

Fig. 27. The daily average wind force according to Beaufort scale during the survey operations.

During the survey there were dramatic changes in water temperature $\left(-2^{\circ} \mathrm{C}\right.$ to $\left.+9^{\circ} \mathrm{C}\right)$ and salinity, making depth control of the streamer difficult. The combination of a high ship speed, together with a fairly heavily balanced and deep towed streamer with a good number of depth controllers (10 birds), was, however, quite successful in overcoming the problem. It also probably helped during marginal sea conditions.

Along the South-East Greenland shelf the pack ice stayed unusually long; by late August it had retreated to approximately $68^{\circ} \mathrm{N}$ and started to advance south as early as mid September (fig. 28). Late in the survey, shooting in ice free channels in pack ice was attempted. During such an operation on 25th September the streamer was lost in an unpredicted hurricane (force 12, Beaufort). Safety regulations demanded immediate evacuation from the ice area. The search for the streamer was continued by the ice reconnaissance aircraft, using Isafjorour as a base. The streamer was not spotted and the area in general was totally inaccessible without ice breaker assistance. Given the time of the year and the expected ice and weather conditions for October it was decided not to await delivery of a new cable. Accordingly the survey vessel was demobilised in Reykjavik on the 28th September.

\section{Survey programme}

A seven week survey programme was planned for 1981 in order to complete the whole NAD acquisition programme. However, only four weeks work was possible and thus the remaining 3-4 weeks programme will have to be completed in the summer of 1982 .

Surveying in four different areas together with a linkage programme was planned for the 1981 operations. The survey areas planned initially were (1) outer shelf and slope region latitude $62^{\circ} \mathrm{N}$ to $65.5^{\circ} \mathrm{N}$; (2) Denmark Strait region; (3) shelf region latitude $68.5^{\circ} \mathrm{N}$ to $70^{\circ} \mathrm{N}$; (4) shelf region north of latitude $72^{\circ} \mathrm{N}$; (5) linking up all sub-programmes made during 1980 and 1981. Areas 1 and 2 were almost completed according to programme and part of the linkage programme was made. Due to extensive pack ice it was not possible to visit areas 3 and 4.

In addition to the reflection seismic programme, a refraction programme consisting of 20 sonobuoy refraction profiles was made. Refraction profiles, typically 20 to $30 \mathrm{~km}$ in length, 

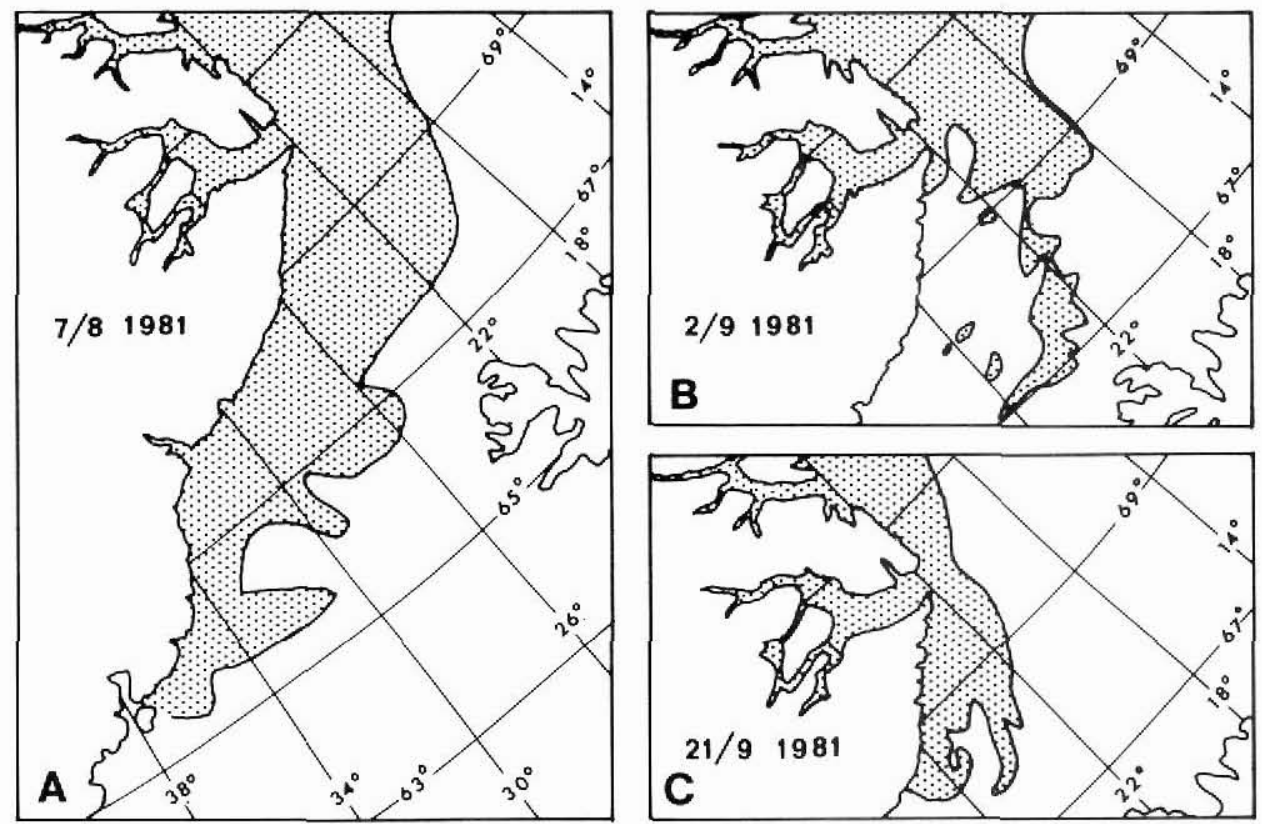

Fig. 28. Ice pattern off East Greenland at start, mid and end of survey.

are fairly evenly spaced throughout the reflection programme area. Emphasis was laid on velocity stratigraphy from the deepest part of the sedimentary basin and information about crustal nature was hopefully also obtained. In principle, all refraction profiles are single profiles, but deep reflection seismic data were obtained along all profiles, thus providing good control of regional dip. In a few cases, sonobuoys were deployed both from the ship and $30 \mathrm{~km}$ ahead of the ship by helicopter, thus providing down-dip as well as up-dip shooting of the same profile.

\section{Data quality and processing}

A thorough examination of data quality must await the processing. However, initial inspection suggests that the quality is generally good. The data quality is rarely affected by factors such as incipient streamer noise due to the state of the sea and course changes necessitated by pack ice and icebergs. However, most lines were shot continuously and straight during good conditions and with a high technical standard. Quality control during acquisition was exercised on behalf of GGU by Exploration Consultants Ltd. in co-operation with two GGU geophysicists. By far the most serious and continuous data problem was sea-bed multiples. This can also be seen in the 1980 data (GGU file). Thus experimental reprocessing has been started on 1980 data from Scoresby Sund where the problem is most serious (see Andersen et al., 1981, for track map). Initial processing of 1981 data reveals the 

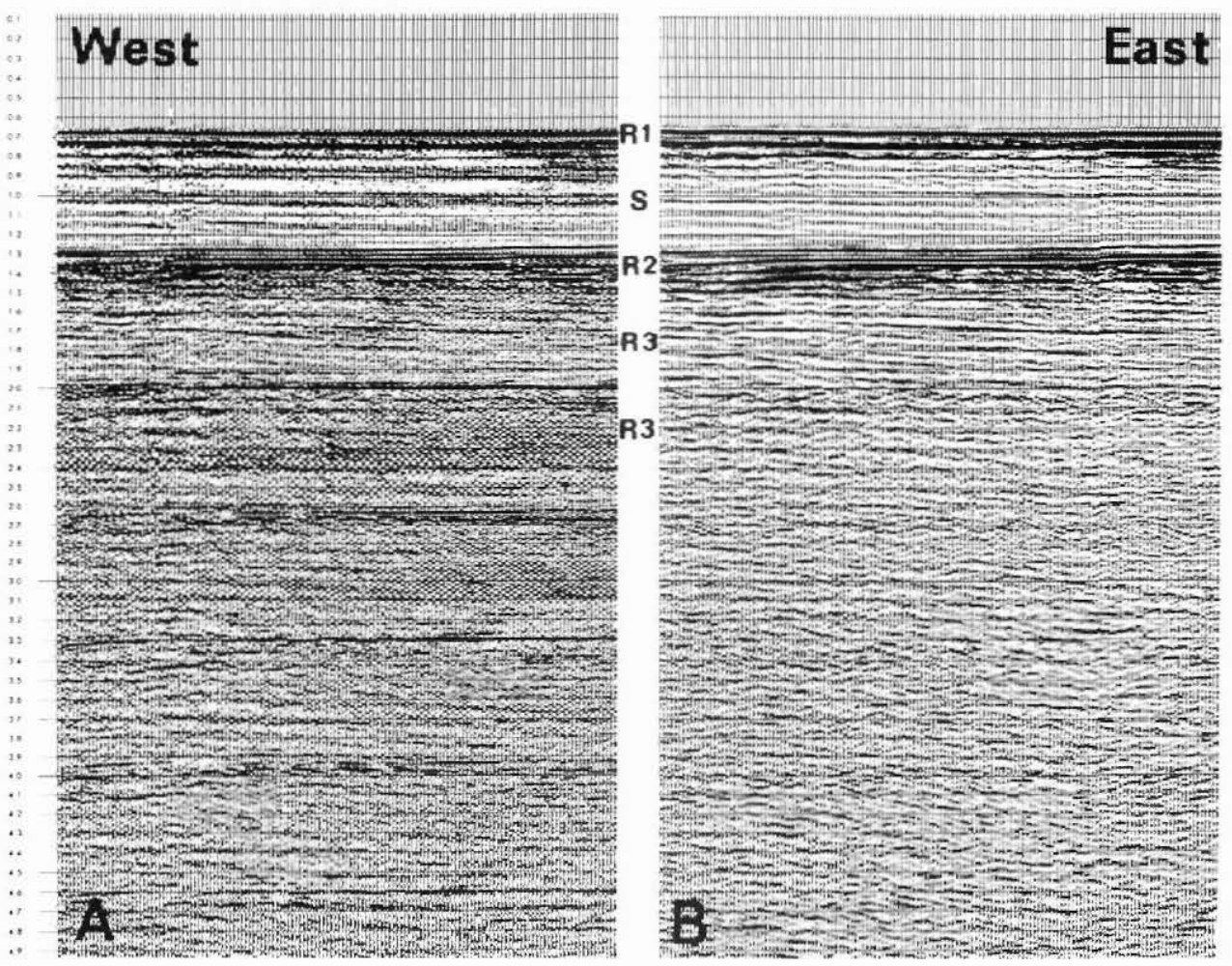

Fig. 29. Part of seismic line $81-1$, final CDP stack. A: no multiple attenuation, B: same panel with $F / K$ multiple attenuation filter applied before stack, R1: sea-bed, S: sediments, R2: basalts, R3: intra-basaltic dipping reflectors.

same problem. This was not unexpected as occasionally even the fifth to sixth order sea-bed multiple was physically audible onboard the survey vessel.

Processing of the 1981 marine geophysical data will take place at Merlin Profiler, Oslo. Processing will include a $\mathrm{F} / \mathrm{K}$ multiple attenuation filter before stack on all profile lines (fig. 29).

Acknowledgements. We thank the seismic crew with Klaus B. Maier as party chief. the crew of the R/V Nina Profiler, the helicopter crew of OY-HSA, Ken Henderson of Exploration Consultants Ltd. and Poul S. Hansen of the Danish Hydraulic Institute for their co-operation during the productive, but turbulent survey operations.

The NAD project is funded by the European Economic Community (EEC) and by the Danish Ministry of Energy. The Denmark Strait project is funded by the Danish Natural Science Research Council.

\section{References}

Andersen, M. S., Larsen, H. C., Risum, J. B. \& Thorning, L. 1981: Geophysical investigations offshore East Greenland - Project NAD. Rapp. Gronlands geol. Unders. 105, 56-60.

6 Rapport nr. 110 
Larsen, H. C. 1980: Geological perspectives of the East Greenland continental margin. Bull. geol. Soc. Denmark 29, 77-101.

Larsen, H. C. \& Thorning, L. 1980: Project EAsTMar: acquisition of high sensitivity aeromagnetic data off East Greenland. Rapp. Grønlands geol. Unders. 100, 91-94.

Risum, J. B. 1980: Project NAD - Part 2: a marine geophysical project offshore East Greenland. Rapp. Grønlands geol. Unders. 100, 99-101.

\section{Establishment of a new survey station at Tasersiaq}

\section{Ole B. Olesen}

As part of the GGU programme for the regional mapping of the hydroelectric potential of West Greenland a new glaciological field station was established during August and September this year. The new station is situated at $66^{\circ} 6.5^{\prime} \mathrm{N}, 50^{\circ} 7.3^{\prime} \mathrm{W}$ near the long $(73 \mathrm{~km})$ and narrow (1.5-2 km) lake Tasersiaq just east of Sukkertoppen Ice Cap (fig. 30).

With an estimated hydroelectric potential of more than $1000 \mathrm{GWh} /$ year (GTO, September 1980) the Tasersiaq basin ranks as one of the largest potential sources of energy from the westcoast basins.

\section{The Tasersiaq basin}

The Tasersiaq basin, excluding its Inland Ice sector, covers an area of $1900 \mathrm{~km}^{2}$, of which $465 \mathrm{~km}^{2}$ are ice covered and $225 \mathrm{~km}^{2}$ are lakes, with the lake system Tasersiaq and Tasersiap qalia together occupying $144 \mathrm{~km}^{2}$. Adjoining this area to the east is a $2030 \mathrm{~km}^{2}$ sector of the Inland Ice contributing to the runoff of the basin thus giving a total drainage area of $3930 \mathrm{~km}^{2}$.

Tasersiaq, at a height of $680 \mathrm{~m}$ above sea level, divides the basin into two morphologically different areas. The northern area is a relatively flat plateau at about $1000-1200 \mathrm{~m}$ above sea level with only a few peaks at $1400-1500 \mathrm{~m}$. This area contains numerous smaller lakes and about 80 very small and scattered glaciers and perennial snow patches ranging from less than $0.1 \mathrm{~km}^{2}$ to $1.3 \mathrm{~km}^{2}$ and totalling $14.3 \mathrm{~km}^{2}$.

The southern part of the basin is dominated by three local ice caps, Sukkertoppen Ice Cap to the west, 'Qârajugtoq ice cap' in the middle and the smaller 'Amitsulôq ice cap' to the east. The total area of the three ice caps within the boundaries of the basin is $422 \mathbf{k m}^{2}$. The heights range from the level of Tasersiaq up to about $1800 \mathrm{~m}$ above sea level. The highest level of the transient snow line in the innermost part of the basin was about $1100 \mathrm{~m}$ at the end of the ablation season at the beginning of September this year. 